\title{
The Master Hoof (Claw) Care Program: Summary Statistics From Three Years ${ }^{1}$
}

\author{
Jan K. Shearer, S. R. Van Amstel, A. Gonzalez-Sagues, and L. C. Shearer ${ }^{2}$
}

Lameness is recognized as one of the most costly clinical diseases of dairy cattle in North America. In large herds the sheer number of lame cows requires that dairies maintain good handling facilities and properly trained personnel for daily care of lameness conditions. In 1996, through a grant from the Florida dairy farmers, the Master Hoof Care Program was developed at the University of Florida. The objective of this program was (and is) to train dairy health care technicians and others in proper methods of foot care and claw trimming. The program is offered three times per year at the University of Florida and once annually at the University of Tennessee. In addition, since many employees on dairy farms throughout the United States are from Mexico or Central and South America, one of the three programs conducted in Florida is presented in Spanish with the assistance of Dr. Adrian Gonzalez from Spain. The course is divided into three parts. Part I of the course consists of one day of classroom instruction and three days of laboratory exercises at cooperating dairy farms. Course content is based on the Dutch trimming method described by Toussaint Raven. Part II of the course is conducted at the participants' homes or places of work where they may continue to practice and further develop their skills before returning to either the University of Florida or Tennessee to complete Part III, a written/oral and laboratory practical examination. As of the writing of this abstract, 194 persons have taken part I of the course. Of these, 19 identified themselves as owners of dairy farms, 102 as dairy health care technicians (dairy farm employees), 25 as professional hoof trimmers, 10 as veterinarians, and 9 as agri-business workers. The remaining persons serve in academia or other areas related to the dairy industry. Participants have come from 30 states (within the USA) and from 6 countries outside the USA. To date, 17 people have successfully completed Part III, and three of these currently serve as laboratory instructors in the course. Participating dairy operations that have established foot care and claw trimming programs as a result cite a reduction in the premature loss of cows to lameness as one of the most noticeable economic benefits observed. This has prompted some dairies to expand their programs beyond the care of lame cows to include maintenance trimming programs. Several participants have taken the course and subsequently started claw trimming businesses. Still others (dairy farmers, veterinarians, and persons in agri-business)

1. This document is VM145, one of a series of the College of Veterinary Medicine-Large Animal Clinical Sciences, Florida Cooperative Extension Service, Institute of Food and Agricultural Sciences, University of Florida. Original publication date August 7, 2002. Visit the EDIS Web Site at http://edis.ifas.ufl.edu.

2. Jan K. Shearer, D.V.M., Professor, College of Veterinary Medicine - Large Animal Climical Sciences, Cooperative Extension Service, University of Florida, Gainesville, 32611. S. R. Van Amstel, Associate Professor, College of Veterinary Medicine, University of Tennessee, Knoxville. A. Gonzalez-Sagues, ANKA Hoof Care, Pamplona, Spain - Private Veterinarians and Hoof Trimmers. L. Shearer, Course Coordinator, University of Florida.

The Institute of Food and Agricultural Sciences is an equal opportunity/affirmative action employer authorized to provide research, educational information and other services only to individuals and institutions that function without regard to race, color, sex, age, handicap, or national origin. For information on obtaining other extension publications, contact your county Cooperative Extension Service office. Florida Cooperative Extension Service/Institute of Food and Agricultural Sciences/University of Florida/Christine Taylor Waddill, Dean. 
have taken the course with little intention to later treat

or trim claws. Instead, they simply wanted to have a better understanding of foot problems and claw

trimming procedures. 